\title{
PENINGKATAN KINERJA PENDIDIK PAUD DALAM PENGEMBANGAN KEMAMPUAN KINESTETIK
}

\author{
Andun Sudijandoko \\ Universitas Negeri Surabaya (e-mail: andunsudijandoko@yahoo.com; \\ HP. 081931052263)
}

\begin{abstract}
The Improvement of ECE Educators' Performance in Developing the Kinesthetic Quotient. This study aims to improve the performance of Early Childhood Education (ECE) educators at the TAPAS Al-Ikhlas BPPNFI Regional IV Surabaya so that they are capable of developing children's kinesthetic qoutient through the concepts of ECE and kinestetic teachinglearning. This study was a classroom action research study. The data were collected through interviews, observations, and documents and were analyzed by means of data reduction, data display, data verification, and conclusion drawing. The findings showed that: (1) before the action was implemented, the kinesthetic teaching-learning model was teacher-centered, the educators did not understand kinesthetic learning concept and learning psychology, the classroom management was not well implemented, and the teaching style was monotonous, (2) after the action was implemented, the educators' teaching skills improved, they employed a variety of teching styles, they understood ECE concepts better, and they were willing to accept changes and committed to making changes.
\end{abstract}

Keywords: Early Childhood Education, Kinesthetic Qoutient

\section{PENDAHULUAN}

DisahkannyaUndang-Undang Nomor 20 Tahun 2003 tentang Sistem Pendidikan Nasional yang secara eksplisit mencantumkan tentang Pendidikan Anak Usia Dini (pasal 28) menunjukkan adanya komitmen bangsa Indonesia untuk menempatkan Pendidikan Anak Usia Dini sebagai bagian penting dalam penyiapan Sumber Daya Manusia (SDM) di masa mendatang. Keberadaan Pendidikan Anak Usia Dini (PAUD) sudah menjadi bagian dari sistem pendidikan nasional, bahkan dapat dikatakan bahwa Pen- didikan Anak Usia Dini merupakan tonggak awal dari serangkaian pendidikan yang diterima oleh anakanak.

KesadaranpentingnyaPAUD telah mendorong pemerintah, dalam hal ini Kementrian Pendidikan Nasional, untuk membentuk sebuah Direktorat baru yang khusus menangani Pendidikan Anak Usia Dini, yaitu Direktorat Pendidikan Anak Usia Dini (Direktorat PAUD). Dengan dibentuknya Direktorat ini, diharapkan dapat mendorong dan memfasilitasi masyarakat di bidang layanan PAUD. Sehingga 
anak-anak Indonesia tidak hanya mengenal pendidikan saat masuk sekolah dasar, tetapi telah lebih dahulu dibina di PAUD.

PAUD merupakan upaya pembinaan yang ditujukan kepada anakanak sejak lahir sampai dengan usia enam tahun, pembinaan dilakukan melalui pemberian rangsangan pendidikan untuk membantu pertumbuhan dan perkembangan jasmani dan rohani agar anak memiliki kesiapan untuk memasuki pendidikan lebih lanjut. Dengan demikian, PAUD merupakan pendidikan awal untuk landasan pendidikan anak selanjutnya. PAUD merupakan bagian integral dalam Sistem Pendidikan Nasional. Dewasa ini, PAUD mendapat perhatian sangat besar dari pemerintah. Hal ini terlihat dari beberapa program yang telah digulirkan oleh Direktorat PAUD, misalnya Sosialisasi Program, bertujuan untuk memberikan penyadaran kepada masyarakat tentang betapa pentingnya PAUD, sedangkan para pendidik juga diberikan diklat agar menambah wawasan dan keterampilan.

Tujuan utama PAUD adalah memfasilitasi tumbuh-kembang anak sejak awal yang meliputi aspek fisik, psikis dan sosial secara menyeluruh. Dengan demikian, anak diharapkan lebih siap untuk belajar lebih lanjut. Hal ini sesuai dengan tujuan kegiatan pendidikan bagi anak usia dini sebagaimana yang tercantum dalam acuan menu pembelajaran pada PAUD (Menu Pembelajaran Generik) tahun 2002. Secara umum, tujuan pendidikan bagi anak usia dini adalah un- tuk mengembangkan berbagai potensi anak sejak dini sebagai persiapan untuk hidup dan dapat menyesuaikan diri dengan lingkungannya.

Masalahnya adalah bagaimana agar layanan PAUD dapat diberikan secara optimal sesuai dengan kebutuhan, karakteristik dan tumbuh kembang anak. Balai Pengembangan Pendidikan Non Formal dan Informal (BPPNFI) Regional IV Surabaya, sebagai Unit Pelayanan Pusat yang salah satu perannya adalah melaksanakan program peningkatan mutu Pendidik dan Tenaga Kependidikan Pendidikan Non Formal (PTK-PNF). Penyelenggaraan pendidikan non formal (PNF) merupakan bagian dari upaya perluasan akses dan peningkatan mutu layanan pendidikan bagi masyarakat

Pendidik PAUD, sebagai orang yang paling dekat dengan anak-anak ketika berada di lembaga PAUD dan sebagai ujung tombak dalam kegiatan pembelajaran di lembaga PAUD, mempunyai peran yang sangat strategis dan penting untuk membantu anak-anak dalam mengembangkan potensi yang mereka miliki. Pendidik PAUD merupakan suatu profesi yang memfokuskan kajiannya pada tumbuh kembang anak. Salah satu bidang kajiannya adalah perkembangan kemampuan kinestetik atau gerak. Agar Pendidik PAUD mampu melakukan bimbingan dan pembelajaran untuk mengembangkan keterampilan kinestetik anak, ia perlu memiliki pemahaman dan kemampuan tentang konsep PAUD dan konsep pembelajaran kinestetik. 
PAUD merupakan upaya pembinaan yang ditujukan bagi anak usia 0 - 6 tahun. Menurut Menu Pembelajaran Generik dinyatakan bahwa Pendidikan Anak Usia Dini adalah:

"Suatu upaya pembinaan yang ditujukan kepada anak sejak dini usia yang dilakukan melalui pemberian rangsangan pendidikan untuk membantu pertumbuhan dan perkembangan jasmani dan rohani agar anak memiliki kesiapan dalam memasuki pendidikan dasar dan kehidupan tahap berikutnya". (Menu Pembelajaran Generik: 2002: 3).

Di dalam Undang-Undang Sisdiknas Tahun 2003 Bagian Ketujuh (pasal 28) Pendidikan Anak Usia Dini disebutkan sebagai berikut.

Pendidikan anak usia dini diselenggarakan sebelum jenjang pendidikan dasar.

> Pendidikan anak usia dini dapat diselenggarakan melalui jalur pendidikan formal, non formal, dan atau informal.

Pendidikan anak usia dini pada jalur pendidikan formal berbentuk taman kanak-kanak (TK), Raudatul Athfal (RA), atau bentuk lain yang sederajat.

> Pendidikan anak usia dini pada jalur pendidikan nonformal berbentuk kelompok bermain (KB), taman penitipan anak (TPA), atau bentuk lain yang sederajat.

Pendidikan anak usia dini pada jalur pendidikan informal berbentuk pendidikan keluarga atau pendidikan yang diselenggarakan oleh lingkungan.

Sasaran utama pendidikan anak usia dini adalah anak lahir sampai dengan usia 6 tahun utamanya yang belum mendapat layanan PAUD, prioritas usia 2-4 tahun. Sedangkan sasaran antara, pendidikan anak usia dini adalah orang tua/keluarga, calon orangtua, pendidik dan pengelola PAUD, serta semua lembaga layanan anak usia dini, para tokoh masyarakat dan stakeholders PAUD.

Tujuan PAUD tidak hanya memberikan pengalaman belajar atau tempat bermain, tetapi juga mengoptimalkan otak, memberikan dukungan bagi kelangsungan hidup dan tumbuh kembang, mengembangkan berbagai potensi anak sejak dini sebagai persiapan untuk hidup dan dapat menyesuaikan diri dengan lingkungannya, serta meningkatkan pengetahuan, keterampilan, dan kesadaran orang tua dan masyarakat terhadap pentingnya PAUD. Hal ini senada dengan pendapat yang dikemukan Fasli Jalal dalam buku Acuan menu pembelajaran pada Pendidikan Anak Usia Dini (Menu Pembelajaran Generik) dikatakan bahwa:

"Hadirnya teori baru tentang Multiple Intelegences juga mengingatkan kepada kita bahwa setiap anak memiliki beberapa potensi kecerdasan. Potensi kecerdasan tersebut akan berkembang secara optimal bila dikembangkan sejak dini melalui layanan pendidikan yang tepat dan sesuai dengan tingkat perkembangan anak".

Penciptaan kondisi belajar bertujuan untuk mengembangkan potensi peserta didik sesuai dengan minat bakat dan kemampuannya. Jadi ketepatan dalam penciptaan kondisi 
dalam belajar sangat membantu anak untuk berkembang dengan baik.

Banyak orang yang sukses tidak semata-mata karena kemampuan kognitifnya saja, tetapi juga karena adanya kemampuan lain yang mereka miliki sehingga mereka bisa sukses dan bertahan dalam hidupnya. Salah satu kemampuan tersebut adalah kecerdasan kinestetik. Seorang Maradona atau Pele misalnya, pemain sepak bola legendaris yang dikenang karena kemampuan dan kepiawiannya dalam mengutak-atik dan mengolah bola mampu membuat orang kagum dan memujinya, bahkan ia dijadikan sebagai idola bagi generasi berikutnya. Begitu pula Andree Agassi, yang sangat lincah memainkan bola tenis dengan ayunan raketnya membuat orang menoleh ke kanan dan ke kiri mengikuti arah gerakan bola dan diselingi tepuk tangan yang meriah, ia mampu menorehkan prestasi dunia. Pun, Tiger Wood yang sejak dini sudah diperkenalkan dengan golf oleh sang ayah, kecerdasan kinestetiknya diasah dengan berbagai pendekatan yang tepat dan baik, lalu dipraktikkan dengan keseriusan, ketekunan dan kedisiplinan yang terkontrol, lahirlah pegolf muda dengan teknik yang benar dan hasil pukulan yang akurat sehingga di usia belasan tahun Tiger sudah mampu menjuarai pertandingan golf yang berskala internasional.

Menurut Hunsicher (1963) dan Corbin (1980) dalam Lumintuarso (2006:4), bahwa:

“.....Momentum yang paling tepat untuk tingkah laku anak melalui program aktivitas jasmani adalah pada usia antara 3 - 4 tahun, sebab pada usia tersebut merupakan "usia kritis" untuk belajar sesuatu"..... "Semakin banyak pengalaman masa kecil semakin besar peluang mereka untuk menemukan potensi terbaiknya dibidang tertentu. Ini berarti bahwa pada masa ini anak perlu mendapatkan pengalaman gerak yang beraneka ragam (multi lateral)".

Menurut Howard Gardner dalam Faruq (2007:1) ada delapan macam kecerdasan yang dimiliki oleh manusia, yaitu kecerdasan Linguistic-Verbal, Logical - Mathematical, Visual - Spatial, Musical-Rhythmic, Interpersonal, Intrapersonal, Naturalist, dan kecerdasan kinestetik, lebih pada kemampuan bergerak, dan sangat senang dengan dunia olahraga, performance, dan menari (Bodily-Kinesthetic).

Dari pendapat di atas, dapat disimpulkan bahwa setiap orang mempunyai kemampuan untuk mengembangkan kecerdasan yang dimilikinya. Salah satu kecerdasan yang dimiliki itu adalah kecerdasan kinestetik. Pengembangan kecerdasan kinestetik anak memang harus ditangani sejak dini dan dengan pendekatan yang baik dan benar. Jika pendekatan itu keluar dari konsep yang benar maka akan terjadi kecenderungan anak hanya melakukan sesuai yang dicontohkan.

Dalam mengembangkan kecerdasan kinestetik (kecerdasan gerak), kita perlu lebih mengenal secara mendalam gerak apa saja yang perlu dikembangkan. Menurut Faruq (2007:5): "Gerak terbagi atas tiga macam yakni gerak lokomosi, gerak nonlokomosi 
dan gerak manipulasi. Selain itu, terdapat tiga tahap dalam mempelajari gerak, yakni tahap kognisi, fiksasi dan yang terakhir adalah otomatisasi".

Dari beberapa pendapat di atas, dapat peneliti simpulkan bahwa perkembangan kinestetik atau gerak bisa terjadidenganbaik apabila anak memperoleh kesempatan cukup besar untuk melalukan aktivitas fisik dalam bentuk gerakan-gerakan yang melibatkan keseluruhan bagian anggotaanggota tubuh yang dilakukan sejak usia dini. Gerakan-gerakan dalam bentuk aktivitas fisik tersebut antara lain: berjalan, berlari, meloncat, melompat, menyepak, menendang, melempar, menangkap, memantul bola, memukul dan berenang.

Istilah "belajar" merupakan sesuatu yang telah biasa didengar di dalam pembicaraan sehari-hari. Psikolog Kimble dan Garmezy (1963) dalam Soemosasmito (1994:28) mendefinisikan belajar sebagai:

"Usaha mencari dan memperoleh pengetahuan dari suatu mata pelajaran atau pelatihan dengan menelaah, mengalami atau belajar atau kecenderungan mengubah perilaku yang relatif permanen sebagai hasil pelatihan yang diperkuat secara berulang kali".

Menurut Maksum (2007:6), belajar adalah;

"Proses perubahan tingkah laku akibat pengalaman. Tingkahlaku bisa berarti sesuatu yang tampak seperti berjalan, berlari, berenang, melakukan shooting, pun juga bisa berarti sesuatu yang tidak tampak seperti berpikir, bersikap dan berperasaan. Adapun pengalaman bisa berbentuk membaca, mendengar- kan, melihat, melakukan baik secara mandiri maupun bersama orang lain."

Jelas bahwa belajar menimbulkan perubahan-perubahan pada diri si pembelajar, dan perubahan yang terjadi dihasilkan dari pengalaman atau berbuat berulang. Pengertian tentang belajar gerak tidak terlepas dari pengertian belajar pada umumnya. Belajar gerak merupakan sebagian dari belajar. Sugiyanto, dkk (1998:268) dalam bukunya Perkembangan dan Belajar Motorik menyatakan bahwa: “Belajar yang menekankan pada aktivitas berpikir bisa disebut belajar kognitif. Belajar yang menekankan pada aktivitas emosi dan perasaan bisa disebut belajar afektif. Sedangkan belajar yang menekankan pada aktivitas gerak tubuh disebut belajar gerak".

Menurut Hurlock (1978:156), masa kanak-kanaksangat ideal untuk mempelajari keterampilan motorik. Ada lima alasan yang mendasari, seperti berikut.

> Tubuh anak lebih lentur dari pada tubuh remaja atau orang dewasa, sehingga anak lebih mudah menerima pelajaran.

Anak masih belum banyak memiliki keterampilan yang akan berbenturan dengan keterampilan yang baru dipelajari, maka bagi anak mempelajari keterampilan yang baru itu lebih mudah.

Anak lebih berani pada waktu kecil dari pada setelah ia besar nanti, mereka lebih berani mencoba sesuatu yang baru. 
Anak-anak lebih suka melakukan pengulangan-pengulangan, sehingga pola otot terlatih untuk melakukannya secara efektif.

Anak memiliki tanggung jawab dan kewajiban yang lebih kecil daripada yang akan mereka miliki saat besar nanti, sehingga anak lebih banyak memiliki waktu untuk mempelajari keterampilan.

Domain fisik dan domain psikomotor menurut Sugiyanto, dkk (1998: 269) merupakan titik sentral di dalam belajar gerak. Belajar gerak terjadi dalam bentuk atau melalui respon-respon muskular yang diekspresikan dalam gerakan-gerakan bagian-bagian tubuh secara sebagian-sebagian atau secara keseluruhan. Aspek utama belajar keterampilan gerak ialah tercapainya otomatisme, melakukan gerakan-gerakan yang sudah otomatis merupakan puncak belajar keterampilan gerak.

Pendidikan yang berkualitas hanya ada pada lembaga pendidikan yang berkualitas, oleh sebab itu upaya peningkatan mutu lembaga pendidikan merupakan titik strategis untuk mencapai pendidikan yang berkualitas. Kualitas pembelajaran sangat ditentukan oleh pendidik, yaitu seberapa tinggi kinerja yang ditampilkan dalam menyelenggarakan proses pembelajaran mulai persiapan sampai penilaian.

Tantangan nyata Pendidikan Anak Usia Dini adalah belum semua guru memanfaatkan lingkungan sebagai media dan sumber pembelajaran, belum semua masyarakat tahu tentang konsep PAUD, taman kanak- kanak hanya dipahami sebagai institusi persiapan untuk masuk SD. Mutu, bahan ajar, sarana prasarana, perubahan konsep belajar yang berimplikasi pada pengabaian tahap tumbuh kembang serta irama belajar anak.

Berdasarkan uraian latar belakang dan kajian teoretik di atas, maka peneliti menemukan permasalahan sebagai berikut. Pendidik PAUD belum sepenuhnya menguasai kecakapan konsep yang meliputi Konsep PAUD dan Konsep Pembelajaran Kinestetik. Karenanya, keterampilan pendidik PAUD perlu ditingkatkan agar mereka mampu melaksanakan proses pembelajaran PAUD yang mengembangkan kemampuan kinestetik anak melalui lokakarya dalam rangka meningkatkan kinerja pendidik PAUD di TAPAS AL-IKHLAS BPPNFI Regional IV Surabaya.

\section{METODE}

Dalam rangka meningkatan kinerja Pendidik Pendidikan Anak Usia Dini (PAUD) dalam pengembangan kemampuan kinestetik (Kinestetic Qoutient), penelitian ini menggunakan pendekatan penelitian tindakan kelas. Classroom Action Research (CAR) atau Penelitian Tindakan Kelas (PTK) adalah action research yang dilaksanakan oleh guru di dalam kelas. Action research pada hakikatnya merupakan rangkaian "Riset-tindakan-riset-tindakan....", yang dilakukan secara siklus, dalam rangka memecahkan masalah, sampai masalah itu terpecahkan. Ada beberapa jenis antion research, dua di antaranya adalah individual 
action research dan collaborative action research, dua-duanya merujuk pada hal yang sama (Depdikbud, 1999). Action Research, lebih bertujuan untuk memperbaiki kinerja/keterampilan, sifatnya kontekstual dan hasilnya tidak untuk digeneralisasikan.

Dalam rangka meningkatkan kinerja pendidik PAUD dalam pengembangan kemampuan kinestetik, penelitian ini menggunakan penelitian tindakan. Penelitian melibatkan mereka yang terlibat di kancah, yaitu: 1) pendidik PAUD; 2) kepala sekolah/koordinator PAUD; 3) siswa. Dalam penelitian ini, peneliti bersama-sama dengan pendidik PAUD yang tidak praktik mengajar serta Koordinator PAUD berusaha mengidentifikasi masalah pembelajaran yang muncul, me- laksanakan tindakan, observasi, melaksanakan refleksi dengan menilai pengaruh, merevisi hasil pembelajaran untuk dikembangkan dalam rencana tindakan berikutnya.

Desain penelitian tersebut dapat digambarkan sebagai kegiatan siklis berkelanjutan oleh Kurt Lewin dalam Sudijandoko A. (2009:2) mengatakan: Sebuah model action research dari Kurt Lewin menjadi acuan pokok atau dasar dari berbagai model action research, terutama Classroom action research (CAR) atau PTK. Konsep pokok action research terdiri empat komponen, yaitu: (1) perencanaan (planning); (2) tindakan (acting); (3) pengamatan (observing); dan (4) refleksi (reflecting). Hubungan keempat komponen itu dipandang sebagai satu siklus.

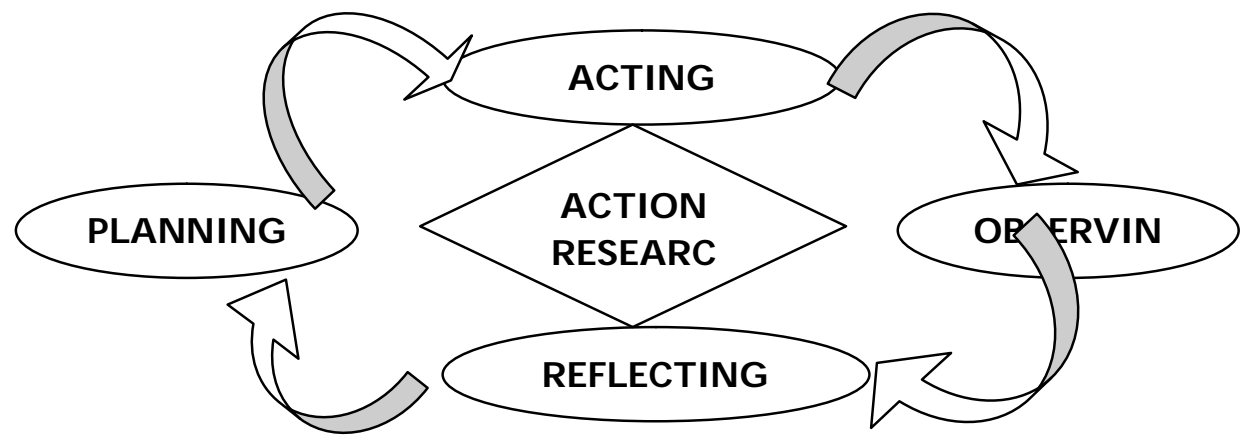

Gambar: 3.1 Siklus Penelitian Tindakan

\section{HASIL DAN PEMBAHASAN}

Memperhatikan permasalahan yang diteliti dan hasil penelitian yang dilaksanakan dalam empat siklus dapat disajikan informasi sebagai berikut.

\section{TEMUAN PUTARAN I}

Menanggapi permasalahan yang ada, maka kegiatan putaran I adalah melaksanakan lokakarya peningkatan kinerja pendidik PAUD dalam mengembangkan kemampuan kinestetik (kinestetic qoutient) dengan peserta sejumlah 8 orang yang terdiri dari 7 orang guru/pendidik PAUD dan 1 orang tenaga administrasi.

Setelah diadakan tanya jawab antara peserta dengan fasilitator diperoleh data sebagai berikut. 
Belum sepenuhnya dipahaminya konsep pendidikan luar sekolah (PLS) atau pendidikan non formal (PNF) dan konsep pembelajaran PAUD.

Belum dipahaminya konsep pembelajaran kinestetik pada PAUD.

Belum dipahaminya teori-teori tentang belajar gerak dalam pendidikan jasmani dan olahraga.

Belum dipahaminya meta teori psikologi pembelajaran yang dapat diterapkan dalam pembelajaran termasuk pada pembelajaran pendidikan anak usia dini.

\section{TEMUAN PADA PUTARAN II}

Walau secara konseptual guru sudah memahami hakekat pendidikan jasmani dan olahraga dan beberapa model pembelajaran yang baik, tetapi dalam tataran implementasi masih banyak dijumpai permasalahan mendasar, seperti berikut.

Ketidaksesuaian antara perencanaan dengan pelaksanaan pembelajaran

Peran guru terlalu dominan sehingga siswa kurang dieksplorasi kreativitas dan partisipasi aktifnya.

$>$ Penggunaan alat/media pembelajaran yang masih relatif kurang relevan dan jumlahnya masih kurang.

Pemanfaatan lapangan yang kurang optimal.

Pendekatan guru dalam mengaktifkan siswa cenderung menggunakan gaya yang monoton, yaitu gaya komando.

> Pemberian kesempatan bagi siswa untuk memperoleh pengalaman dalam menemukan, penyelidikan dan menjalin kerjasama masih kurang.

Sistematika tugas gerak masih belum baik.

Kejelasan instruksi masih menjadi kendala bagi siswa, akibatnya terjadi tugas gerak yang tidak sesuai.

> Pendekatan pembelajaran dengan nuansa bermain sambil belajar masih belum begitu nampak.

Fasilitas masih kurang memadai/ variatif.

Atas dasar permasalahan yang muncul pada putaran II, disusunlah rencana pembelajaran baru yang akan dilaksanakan pada putaran III. Target yang diharapkan tercapai pada putaran lanjutan ini adalah: 1) tidak terulangnya kesalahan-kesalahan pembelajaran yang telah terjadi pada putaran sebelumnya; 2) terjadinya perbaikan atas kesalahan-kesalahan yang telah lalu; 3) telah dioptimalkannya keterampilan guru yang sudah muncul, tetapi masih belum berkembang; dan 4) dikembangkannya inovasi pendekatan pembelajaran yang relevan, konstruktif bagi anak usia dini, sehingga pembelajaran bisa berlangsumg secara efektif, efisen dan menyenangkan.

\section{TEMUAN PADA PUTARAN III}

Berdasarkan hasil temuan dan refleksi di tiga kancah dan temuan permasalahan pada putaran III menunjukkan bahwa meskipun secara konseptual guru sudah memahami konsep PAUD dan beberapa model pembelajaran yang baik, tetapi dalam tataran implementasi masih dijumpai 
permasalahan mendasar, seperti berikut.

Kesalahan-kesalahan yang terjadi pada siklus sebelumnya, sebagian besar tidak terulang, tetapi ada juga sebagian kecil masih terulang, karena dengan siswa yang tidak sama, situasi dan kondisi yang terjadi relatif baru dan berbeda dengan situasi dan kondisi pada siklus sebelumnya.

Kelemahan-kelemahan yang terjadi pada siklus sebelumnya masih belum sepenuhnya mampu diatasi oleh sebagian besar guru, seperti peran guru yang terlalu dominan, guru cenderung mengunakan gaya komando dalam membelajarkan siswa dan pengelolaan kelas yang masih perlu ditingkatkan.

\section{TEMUAN PADA PUTARAN IV}

Hasil observasi dan refleksi pada siklus IV, secara umum diperoleh data dan informasi sebagai berikut.

Sebagian besar kesalahan-kesalahan yang terjadi pada siklus II dan III tidak terulang pada siklus berikutnya, tetapi ada juga yang masih mengulanginya, hal ini disebabkan karena dengan siswa yang tidak sama, situasi dan kondisi yang terjadi relatif baru dan berbeda dengan situasi dan kondisi pada siklus sebelumnya.

Kelemahan-kelemahan yang terjadi pada siklus sebelumnya mampu diatasi oleh guru/pendidik PAUD.

Pengoptimalan beberapa aspek tentang keterampilan dalam membelajarkan siswa masih menjadi kendala bagi sebagian besar guru/ pendidik PAUD. Hal ini sangat terkait dengan mengubah suatu kebiasaan yang telah lama dilakukan, sehingga memerlukan waktu dan upaya yang berkesinambungan.

Penerapan inovasi model pembelajaran yang konstruktif pada pendidikan anak usia dini nampaknya secara antusias diterima oleh guru/ pendidik PAUD, dan diupayakan terimplementasi dalam setiap pembelajarannya. Penerapan inovasi itu oleh sebagian besar guru/pendidik PAUD disikapi sebagai sesuatu yang menarik, baru dan menantang. Contoh bentuk inovasi yang dilakukan adalah semakin dikembangkan dan ditingkatkannya pembelajaran keterampilan kinestetik/ gerak dalam bentuk permainanpermainan yang relevan dengan karakteristik pendidikan anak usia dini.

\section{KESIMPULAN}

Berdasarkan hasil penelitian tindakan yang telah dilakukan oleh peneliti diperoleh simpulan sebagai berikut.

Sebelum diberikan tindakan, model pembelajaran keterampilan kinestetik/gerak yang diterapkan pendidik PAUD di Tapas Al-Ikhlas BPPNFI Regional IV Surabaya masih berorientasi atau berpusat pada pendidik, dan pendidik PAUD belum memahami konsep pembelajaran kinestetik/gerak serta belum memahami meta teori psikologi pembelajaran, pengelolaan kelas belum optimal, gaya mengajar yang digunakan masih monoton 
(gaya komando). Hal tersebut terlihat pada siklus I dan II.

Pada siklus III, diperoleh temuan sebagai berikut. Terjadi perbaikan keterampilan mengajar pendidik PAUD yang ditunjukkan dengan meminimalisir kesalahan yang dilakukan pada siklus II walaupun masih terdapat kelemahan-kelemahan seperti gaya komando terkadang masih dilakukan.

Pada siklus IV diperoleh temuan bahwa terjadi perbaikan keterampilan mengajar pendidik PAUD dengan tidak terulangnya kesalahan pada siklus II dan III, guru/pendidik PAUD antusias dalam menerima perubahan dan berkomitmen akan menerapkannya dalam pembelajaran mereka. Hal tersebut dapat diartikan pula adanya peningkatan keterampilan pendidik PAUD di Tapas Al-Ikhlas BPPNFI Regional IV Surabaya dalam mengembangkan kemampuan kinestetik.

Perhatian dari Balai Pengembangan Pendidikan Non Formal dan Informal (BPPNFI) Regional IV Surabaya terhadap kegiatan belajar mengajar di PAUD Tapas Al-Akhlas bertambah. Hal ini dibuktikan dengan memberikan fasilitas dan sarana selama penelitian dilaksanakan.

Bahwa segala hal yang peneliti temukan ini diterapkan di lingkungan kerja BPPNFI Regional IV Surabaya dalam rangka meningkatkan profesionalitas pendidik PAUD.

\section{SARAN}

Berdasarkan simpulan hasil penelitian tersebut, maka ada beberapa hal yang perlu diperhatikan dengan peningkatan keterampilan pendidik PAUD membelajarkan kinestetik/gerak di PAUD Tapas Al-Akhlas Balai Pengembangan Pendidikan Non Formal dan Informal (BPPNFI) Regional IV Surabaya seperti berikut.

Pentingnya memahami meta teori psikologi pembelajaran bagi pendidik PAUD untuk diterapkan dalam pembelajaran.

$>$ Hendaknya pendidik PAUD menggunakan hasil penelitian ini menjadi salah satu bahan pertimbangan dalam upaya meningkatkan kinerja profesinya.

- Untuk BPPNFI Regional IV hasil penelitian ini hendaknya dapat dimanfaatkan sebagai bahan kajian untuk peningkatan kualitas guru/ pendidik PAUD, kemudian dilakukan sosialisasi di wilayah kerjanya.

$>$ Pendidik PAUD hendakya proaktif dalam melaksanakan tugasnya dengan guru/pendidik PAUD yang lain ataupun dengan koordinatornya dalam rangka peningkatan keterampilannya secara berkelanjutan.

Dalam rangka meningkatkan profesionalitas pendidik PAUD, maka perlunya diadakan seminar, lokakarya serta pendidikan dan pelatihan-pelatihan tentang PAUD yang dilaksanakan secara berkembang berkelanjutan.

> Penelitian ini berupaya untuk meningkatkan kinerja dan keterampilan guru/pendidik PAUD dalam 
membelajarkan kinestetik/gerak pada peserta didik. Adapun yang telah diberikan dari penelitian ini adalah bahwa pendidik PAUD di Tapas Al-Ikhlas BPPNFI Regional IV Surabaya dijadikan rujukan bagi pendidik PAUD lainnya. Khususnya, dalam upaya peningkatan kinerja dan keterampilan pendidik PAUD dalam mengembangkan kemampuan kinestetik/gerak pada anak usia dini. Artinya bahwa hasil penelitian ini telah dapat digunakan sebagai bahan rujukan guna meningkatkan kinerja dan keterampilan pendidik PAUD dalam membelajarkan kinestetik/gerak pada anak usia dini.

\section{UCAPAN TERIMA KASIH}

Pada kesempatan ini, terima kasih kami ucapkan kepada Redaktur yang telah memberi masukan yang berharga sehingga tulisan ini dapat disajikan di Jurnal Cakrawala Pendidikan. Terima kasih juga kami ucapkan kepada seluruh pengurus Jurnal Cakrawala Pendidikan yang telah memberi ruang diskusi.

\section{DAFTAR PUSTAKA}

Direktorat Pendidikan Anak Dini Usia, Ditjen Diklusepa. 2002 Acuan Menu Pembelajaran pada Pendidikan Anak Dini Usia (Menu PembelajaranGenerik). Jakarta: Depdiknas.

Faruq, Muhammad Muhyi. 2007. 100 Permainan Kecerdasan Kinestetik. Jakarta: Penerbit PT Gramedia.
Lumintuarso, Ria. 2006. Belajar Gerak. Disajikan dalam Peningkatan Kualitas Sumber Daya Pembina Olahraga Luar Sekolah. Makasar Sulawesi Selatan.

Maksum, Ali. 2006. Metodologi Penelitian dalam Olahraga. Fakultas Ilmu Keolahragaan Universitas Negeri Surabaya.

Mutohir, T. Cholik dan Soemosasmito, S. 1997. Refleksi Landasan Falsafah Pendidikan Jasmani dan Olahraga. Disajikan dalam Konferensi Nasional Pendidikan Jasmani dan Olaharaga, Reorientasi Arah Pembangunan Pendidikan Jasmani dan Olahraga di Indonesia serta Peningkatan Investasi IPTEK Olahraga untuk Mengantisipasi Tantangan Kehidupan pada Abad Ke21. IKIP Bandung.

Salman, Muh. Syukur. 2007. Artikel: Spirit PAUD Nonformal dalam mendukung Wajar 9 Tahun, htt$\mathrm{p}$ ://re-searchengines.com/0607syukur2.html diakses 24-112008.

Sudijandoko, A. 2009, Penelitian Tindakan Kelas, Makalah disajikan pada Seminar PTK Guru-Guru SMP PGRI Se-Kabupaten Sidoarjo, 18 Pebruari 2009.

Sugiyanto, dkk. 1998. Perkembangan dan Belajar Gerak. 1998. Jakarta: Universitas Terbuka. 
Undang-Undang Republik Indonesia No. 20 Tahun 2003. Sistem Pendidikan Nasional. Jakarta: Asa Mandiri.

Undang-Undang Republik Indonesia No. 3 Tahun 2005. Sistem Keolahragaan Nasional. Jakarta: Kementerian Negara Pemuda dan Olahraga Republik Indonesia.

Undang-Undang Republik Indonesia No. 14 Tahun 2005. Guru dan Dosen. Jakarta: Asa Mandiri. 